Vol. 6 (1997): 381-387.

\author{
Research Note
}

\title{
Quality of the ryegrass and lettuce yields as affected by selenium fertilization
}

\author{
Helinä Hartikainen \\ Department of Applied Chemistry and Microbiology, PO Box 27, FIN-00014 University of Helsinki, \\ Finland, e-mail: helina.hartikainen@helsinki.fi \\ Päivi Ekholm, Vieno Piironen \\ Department of Applied Chemistry and Microbiology, PO Box 27, FIN-00014 University of Helsinki, Finland \\ Tailin Xue \\ Institute of Geography of Chinese Academy of Sciences, Beijing 100101, China \\ Terhi Koivu, Markku Yli-Halla \\ Department of Applied Chemistry and Microbiology, PO Box 27, FIN-00014 University of Helsinki, Finland
}

\begin{abstract}
The effect of Se-fertilization on the chemical composition and anti-oxidative properties of ryegrass and lettuce was studied in a pot experiment. The addition of Se enhanced its relative incorporation in soluble and insoluble proteins and diminished it in free amino acids. It also affected the anti-oxidative systems of the plants. The glutathione peroxidase (GSH-Px) activity found in both plant species increased with increasing Se-fertilization, whereas the superoxide dismutase (SOD) activity as well as the concentration of vitamin E decreased. This may indicate that the synthesis of SOD and vitamin $\mathrm{E}$ was reduced because the requirement of these anti-oxidants was diminished by antioxidative function of Se.
\end{abstract}

Key words: anti-oxidants, glutathione peroxidase, Se-fractions, superoxide dismutase, vitamin E

\section{Introduction}

Selenium is an essential element to human and animals. Low Se-intake connected with vitamin E deficiency increases oxidative stress and contributes to the development of oxidative damages (for references see e.g. Mayland 1994). However, at high intake Se is toxic. Typical symp- toms of selenosis are reported for humans in China and animals in USA (Yang et al. 1983, Oldfield 1987). Because of these dual effects it is important to control the concentration of Se in plant products. In global scale, Se-deficient areas are far larger than seleniferous ones (Kubota et al. 1967, Zhen et al. 1982). In Finland the soils are poor in bioavailable Se (Yläranta 1983) and the Se-concentration of crops used 


\section{AGRICULTURAL AND FOOD SCIENCE IN FINLAND}

\section{Hartikainen, $H$. et al. Ryegrass and lettuce yields as affected by selenium fertilization}

to be below the adequate level (e.g. Sippola 1979). Therefore, since 1984 all multinutrient fertilizers produced in Finland have been supplemented with sodium selenate, resulting in a substantial increase in Se in plants and food (Ekholm et al. 1995).

Nevertheless, the role of Se in plants is still unclear. Plant species capable of accumulating Se can assimilate it in different forms into their tissues (Peterson and Burler 1962). Selenium absorbed by the plants can be metabolized partly following the pathway of its chemical analogue sulfur, and it can be synthesized to Se-containing substituents (Shrift and Virupaksha 1965). However, Se in various chemical forms may be dissimilarly utilized by humans or animals, and its effectiveness in increasing the activity of glutathione peroxidase (GSH-Px), an important anti-oxidative enzyme, and Se-concentrations in tissues may vary (Mahan and Moxon 1978, Sankari 1985, Aspila 1991).

The aim of this preliminary pot experiment was to investigate how Se added in increasing amounts is allocated into various compounds in different plant species. To study the effect of Sefertilization on the anti-oxidative properties of plant products and enzyme activities, the yields were also analyzed for the concentration of vitamin E and for GSH-Px and superoxide dismutase (SOD) activities. The study was carried out with ryegrass (monocotydelon), an important forage crop, and with lettuce (dicotydelon), a common vegetable in the human diet.

\section{Material and methods}

\section{Pot experiment}

The soil used in the pot experiment had a $\mathrm{pH}\left(\mathrm{CaCl}_{2}\right)$ of 6.3 and contained $2.8 \%$ of organic carbon. Its particle size composition was: $8 \%$ of clay $(<2 \mu \mathrm{m}), 19 \%$ of silt $(2-20 \mu \mathrm{m})$ and $64 \%$ of fine sand $(20-200 \mu \mathrm{m})$ and $9 \%$ of coarser material. Each pot was filled with $7.43 \mathrm{~kg}$ of moist soil, equivalent to $6.43 \mathrm{~kg}$ of dry matter. The different Se-levels $(0,8,16$ and $33 \mu \mathrm{g}$ Se $\mathrm{kg}^{-1}$ of dry soil, four replicates) were created with two commercial multinutrient compound fertilizers, one virtually devoid of $\mathrm{Se}(18.0 \% \mathrm{~N}, 6.4 \%$ $\mathrm{P}, 13.1 \% \mathrm{~K}$ and $0.1 \mathrm{ug} \mathrm{Se} \mathrm{kg}^{-1}$ ) and one supplemented with sodium selenate during the manufacturing process $(16.6 \% \mathrm{~N}, 7.1 \% \mathrm{P}, 13.3 \% \mathrm{~K}$ and $\left.19 \mathrm{mg} \mathrm{Se} \mathrm{kg}^{-1}\right)$. Small amounts of $\mathrm{Ca}\left(\mathrm{H}_{2} \mathrm{PO}_{4}\right)_{2}$ $\cdot \mathrm{H}_{2} \mathrm{O}$ and $\mathrm{KCl}$ were also applied, when needed, to end up with the same quantities of $\mathrm{N}(1.83 \mathrm{~g})$, $\mathrm{P}(0.78 \mathrm{~g})$ and $\mathrm{K}(1.47 \mathrm{~g})$ in each pot. The pots were sown with 5 seeds of lettuce or $2.5 \mathrm{~g}$ of Italian ryegrass. Lettuce was thinned to three plants in each pot. Deionized water was used for watering.

\section{Plant analyses}

The ryegrass was harvested 21 days and the lettuce 46 days after sowing. To get enough plant material for vitamin and Se-fractionation analyses the fresh yields of all replicates in each treatment were combined and then weighed (FW). After careful mixing, about a quarter of the plant material was immediatedly packed in vacuum bags and stored in a freezer at $-70^{\circ} \mathrm{C}$ for vitamin and enzyme analyses. Then rest of the yield was used for the determination of the dry weight (DW) and Se-analyses. The air-dried plant material was ground and a subsample of about $4 \mathrm{~g}$ was stored in a freezer for the analysis of total Se. The rest of the ground plant material was used to study the allocation of added Se into various compounds.

The Se in the inorganic fraction, in free amino acids and in the insoluble residue was fractionated in two replicates according to GisselNielsen (1987). In addition, the $\mathrm{Se}$ in the soluble proteins was also determined. The supernatants obtained when a 10 -g sample was extracted twice for $20 \mathrm{~min}$ with $100 \mathrm{ml}$ of water and once with $50 \mathrm{ml}$ of water were combined, and the soluble proteins were precipitated with $60 \mathrm{ml}$ of $30 \%$ trichloroacetic acid. The solution was centrifuged in tared tubes for $40 \mathrm{~min}$ at 


\section{AGRICULTURAL AND FOOD SCIENCE IN FINLAND}

Vol. 6 (1997): 381-387.

Table 1. The fresh (FW) and dry weight (DW) of the shoot yields, their Se-concentration and Se-uptake at various Se-addition levels.

\begin{tabular}{|c|c|c|c|c|c|}
\hline \multirow{2}{*}{$\begin{array}{l}\text { Se added } \\
\mu \mathrm{g} \mathrm{kg}^{-1} \text { soil }\end{array}$} & \multirow{2}{*}{$\begin{array}{c}\mathrm{FW} \\
\mathrm{g}\end{array}$} & \multirow{2}{*}{$\begin{array}{c}\text { DW } \\
\mathrm{g}\end{array}$} & \multirow{2}{*}{$\begin{array}{c}\text { Se-conc. } \\
\mu \mathrm{g} \mathrm{g}^{-1} \mathrm{DW}\end{array}$} & \multicolumn{2}{|c|}{ Se-uptake } \\
\hline & & & & $\mu \mathrm{g}$ & $\%$ of added \\
\hline \multicolumn{6}{|c|}{ Ryegrass } \\
\hline 0 & 330 & 36.4 & 0.023 & 0.8 & - \\
\hline 8 & 320 & 35.6 & 2.15 & 76.5 & 36 \\
\hline 16 & 291 & 34.3 & 3.45 & 118.3 & 38 \\
\hline 33 & 301 & 32.3 & 5.05 & 162.9 & 19 \\
\hline \multicolumn{6}{|c|}{ Lettuce } \\
\hline 0 & 574 & 35.4 & 0.022 & 0.8 & - \\
\hline 8 & 640 & 53.6 & 1.52 & 81.5 & 38 \\
\hline 16 & 700 & 62.7 & 2.90 & 181.9 & 43 \\
\hline 33 & 600 & 51.4 & 4.90 & 252.0 & 30 \\
\hline
\end{tabular}

$11000 \mathrm{rpm}$, and the proteins in the precipitate were dried at $40-50^{\circ} \mathrm{C}$ overnight, cooled in a desiccator, weighed and stored in a freezer. The total Se-concentration in plant material (measured in dublicate) and $\mathrm{Se}$ in each fraction was determined by the electrothermal atomic absorption spectrometric method of Kumpulainen et al. (1983). Tocopherols were determined at least in duplicate according to Piironen et al. (1986). SOD activity was determined according to Giannopolitis and Ries (1977) and GSH-Px activity by a modified method of Flohe and Gunzler (1984).

In the fractionation procedure the ion exchange in the amino acid analyses was tested by using a standard sample containing 16 amino acids. Their retention in and elution from the column were checked by the ninhydrin reaction. To control the reproducibility of the Se-analyses, in-house reference samples were included in every determination round. The mean and standard deviation in the reference lettuce sample was $4.609 \pm 0.278(n=7)$. The corresponding figures obtained for the wheat flour sample within the study period $0.257 \pm 0.024(n=7)$ were close to the long-term value of $0.246 \pm 0.008(n=332)$. In tocopherol analyses the recovery of $\alpha$-tocopherol varied from 83 to $115 \%$, and for the wheat germ oil used to control the level of tocopherol analyses the coefficient of variation was $5.1 \%$ $(n=14)$. In the enzyme analyses, the means of the coefficients of variation in the five replicates of each sample were $8.3 \%$ and $15.1 \%$ for GSHPx and $14.1 \%$ and $20.4 \%$ for SOD in ryegrass and lettuce, respectively.

\section{Results and discussion}

\section{The shoot yields and Se-concentrations}

The dry matter yield of the ryegrass tended to decrease slightly with increasing Se applications, whereas that of the lettuce increased (Table 1). At the highest Se-level, however, this positive response diminished. Nevertheless, the beneficial effect of Se found for lettuce in the present study cannot be taken for granted, because the treatments were not equal in the quantities of the commercial fertilizers added and a possible contribution by some trace element cannot be excluded.

In the unsupplemented plants, the Se-concentration (Table 1) was of the magnitude reported for agricultural plants in Finland before Se-supplementation of fertilizers (see Sippola 1979, 


\section{AGRICULTURAL AND FOOD SCIENCE IN FINLAND}

Hartikainen, $H$. et al. Ryegrass and lettuce yields as affected by selenium fertilization

Table 2. Se-concentration in various fractions of the plant material.

\begin{tabular}{|c|c|c|c|c|}
\hline \multirow{2}{*}{$\begin{array}{l}\text { Se added } \\
\mu \mathrm{g} \mathrm{kg}^{-1} \text { soil }\end{array}$} & Inorganic ${ }^{1)}$ & Amino acid" & Sol. proteins & Residue \\
\hline & \multicolumn{2}{|c|}{$\mathrm{ng} \mathrm{ml}^{-1}$} & \multicolumn{2}{|c|}{$\mathrm{ng} \mathrm{g}^{-1} \mathrm{DW}$ of the fraction } \\
\hline \multicolumn{5}{|c|}{ Ryegrass } \\
\hline 0 & 4 & 5 & 78 & 37 \\
\hline 8 & 143 & 15 & 3780 & 2640 \\
\hline 16 & 291 & 38 & 6900 & 3200 \\
\hline 33 & 535 & 67 & 9200 & 4200 \\
\hline \multicolumn{5}{|c|}{ Lettuce } \\
\hline 0 & 9 & 4 & 54 & 35 \\
\hline 8 & 119 & 13 & 2710 & 1860 \\
\hline 16 & 230 & 16 & 4200 & 3650 \\
\hline 33 & 471 & 67 & 7900 & 5600 \\
\hline
\end{tabular}

1) = volume of the fraction was $20 \mathrm{ml}$

Yläranta 1983). In the Se-fertilized plants it was higher than normally found in field crops (cf. Varo 1983, Ekholm et al. 1995). Because lettuce was harvested at a later stage, the uptake of fertilizer Se by the yields was slightly greater than that by ryegrass. In both plants, the utilization of added Se diminished at the highest fertilization level.

\section{Allocation of Se into different fractions}

The figures in Table 2 show that in all treatments the Se concentration in the various fractions followed the order: soluble proteins $>$ insoluble residue $>$ inorganic $>$ amino acids. The Se in the insoluble residue is mainly protein-bound. The relative allocation of Se between various forms was calculated by taking into account the weight of each fraction. Figure 1 reveals that, except for lettuce not amended with Se, the major part of Se in plant material was incorporated into proteins (soluble proteins plus residue). The Se-fertilization further increased the relative portion of protein-bound Se-fraction but decreased that bound by free amino acids. This indicates that the Se taken up was effectively utilized in the protein synthesis.

In ryegrass, the relative portion of insoluble Se-proteins (the residual fraction) seemed to in- crease at the expense of soluble proteins (Fig. 1). This may to some extent be attributable e.g. to the formation of Se-methionine, because it is less water-soluble than its S-containing analogue methionine (Shepherd and Huber 1969). In lettuce the Se-fertilization also seemed to promote the synthesis of Se-containing proteins at the expense of the inorganic fraction, which was high in the control plants. This response was clear at the lowest Se-fertilization level. The result suggests that the nutritional value of the plants can be increased by a reasonable Se-addition, because organic Se is known to be more efficient than inorganic Se in increasing the Se-concentration and GSH-Px activity in plasma and muscle tissue (Mahan and Moxon 1978, Sankari 1985, Aspila 1991),

\section{Vitamin E and enzyme activities}

The two plant species differed in tocopherol compounds $\left(\mathrm{Vit}_{\mathrm{E}}\right)$ detected. $\boldsymbol{\alpha}$-tocopherol dominated in ryegrass and only traces of $\beta$-tocopherol were found (Table 3 ). Lettuce, on the contrary, contained about equal quantities $\alpha$ - and $\gamma$-tocopherols in addition to traces of $\beta$-tocopherol. The Se-fertilization tended to decrease their concentrations. The increase in both tocopherols in lettuce at the highest-Se level was 


\section{AGRICULTURAL AND FOOD SCIENCE IN FINLAND}

Vol. 6 (1997): 381-387.

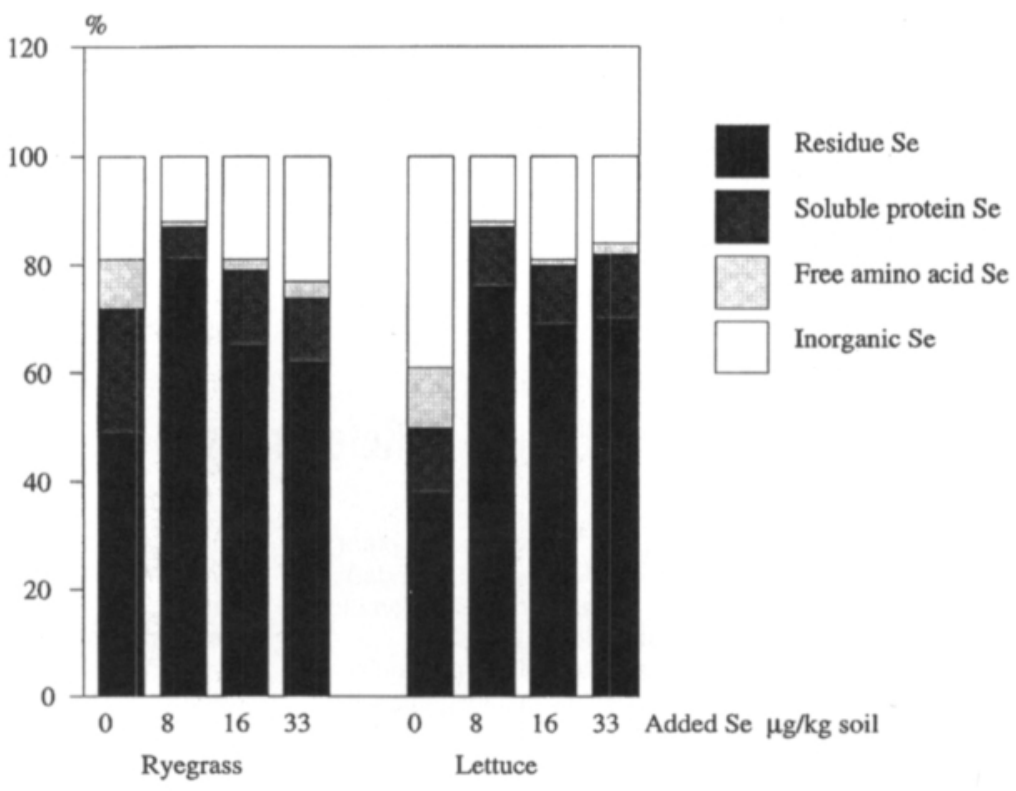

Fig. 1. The relative distribution of various Se-fractions.

the only exception and its reason remained unclear.

GSH-Px and SOD activities were higher in lettuce than in ryegrass (Table 4 ). In both species, the GSH-Px activity seemed to increase with increasing Se-fertilization, whereas an opposite trend was found for SOD. The increasing trend in GSH-Px possibly indicates the presence of Se-dependent GSH-Px in plants. However, further evidence is needed to prove the occurrence of this enzyme in higher plants. Anderson and Scarf (1983) refer to results which showed that in crude extracts of pea shoots catalyzing $\mathrm{H}_{2} \mathrm{O}_{2}$-dependent oxidation of $\mathrm{GSH}$, a flavonoid was needed to express this activity. On the other hand, the opposite trends in GSH-Px and SOD as well as the $\mathrm{Se}$-induced depletion in tocophe-
Table 3. Tocopherol concentrations in the experimental plant species at various Se-addition levels").

\begin{tabular}{lccc}
\hline \multirow{2}{*}{$\begin{array}{l}\text { Se added } \\
\mu g \mathrm{~kg}^{-1} \text { soil }\end{array}$} & $\alpha$ & $\gamma$ & $\Sigma$ \\
\cline { 2 - 4 } & \multicolumn{3}{c}{$\mathrm{mg} \mathrm{kg}^{-1} \mathrm{FW}$} \\
0 & 13.8 & Ryegrass \\
8 & 12.0 & & 13.8 \\
16 & 11.6 & 12.0 \\
33 & 11.3 & & 11.6 \\
& & & 11.3 \\
0 & 5.9 & 5.8 & 11.7 \\
8 & 6.8 & 6.1 & 12.9 \\
16 & 2.1 & 5.1 & 7.2 \\
33 & 9.5 & 10.0 & 19.5 \\
\hline
\end{tabular}

1) The proportion of $\gamma$-tocopherol from the total amount of tocopherols is estimated by comparing its peak area with that of $\alpha$-tocopherol.

Table 4. GSH-Px and SOD activities ( $\mathrm{mg}^{-1}$ protein • $\left.\mathrm{min}\right)$ in the experimental plants at various Se-addition levels ${ }^{1)}$.

\begin{tabular}{lccccc}
\hline & \multicolumn{2}{c}{ Ryegrass } & & \multicolumn{2}{c}{ Lettuce } \\
\cline { 2 - 3 } \cline { 5 - 6 } $\begin{array}{l}\text { Se added } \\
\mu \text { g kg soil }^{-1}\end{array}$ & $\begin{array}{c}\text { GSH-Px } \\
\mu \text { mol }\end{array}$ & $\begin{array}{c}\text { SOD } \\
\text { unit }\end{array}$ & & $\begin{array}{c}\text { GSH-Px } \\
\mu \text { mol }\end{array}$ & $\begin{array}{c}\text { SOD } \\
\text { unit }\end{array}$ \\
\hline 0 & 34.8 & 2.8 & & nd & nd \\
8 & 37.9 & 2.1 & & 119.8 & 5.6 \\
16 & 40.6 & 2.0 & & 129.8 & 2.8 \\
33 & 54.4 & 2.0 & & 160.0 & 3.9 \\
\hline
\end{tabular}

1) $\mathrm{GSH}-\mathrm{Px}=$ glutathione peroxidase SOD $=$ superoxide dismutase $\mathrm{nd}=$ no data 


\section{AGRICULTURAL AND FOOD SCIENCE IN FINLAND}

\section{Hartikainen, H. et al. Ryegrass and lettuce yields as affected by selenium fertilization}

rols are probably due to the fact that Se increased the anti-oxidative capacity of the plants and diminished the substrate for SOD (superoxide anion radical $\mathrm{O}_{2}^{-}$) and $\mathrm{Vit}_{\mathrm{E}}$ (lipid peroxide radical LOO). Therefore, the demand for the synthesis of SOD and $\mathrm{Vit}_{\mathrm{E}}$ could be reduced (Xue et al. 1993).

Acknowledgements. The financial support from the Academy of Finland is gratefully acknowledged.

\section{References}

Anderson, J.W. \& Scarf, A.R. 1983. Selenium and plant metabolism. In: Robb, D.A. \& Pierpoint, W.S. (eds.). Metals and micronutrients: Uptake and utilization by plants. Academic Press. Orlando. p. 241-275.

Aspila P. 1991. Metabolism of selenite, selenomethionine and feed-incorporated selenium in lactating goats and dairy cows. Journal of Agricultural Science in Finland 63: 1-73.

Ekholm, P., Ylinen, M., Koivistoinen, P. \& Varo, P. 1995. Selenium concentration of Finnish foods: Effect of reducing the amount of selenate in fertilizers. Agricultural Science in Finland 4: 377-384.

Flohe, L. \& Gunzler, W.A. 1984. Assays of glutathione peroxidase. In: Packer, L. (ed.). Methods in Enzymology. Vol. 105. Academic Press. New York. p. 114121.

Giannopolitis, C.N. \& Ries, S.K. 1977. Superoxide dismutases: I Occurrence in higher plants. Plant Physiology 59: 309-314.

Gissel-Nielsen G. 1987. Fractionation of selenium in barley and ryegrass. Journal of Plant Nutrition 10: 21472152.

Kubota, J., Allaway, W.H., Carter, D.L., Cary, E.E. \& Lazar, V.A. 1967. Selenium in crops in the United States in relation to selenium-responsive diseases of animals. Journal of Agricultural and Food Chemistry 15: 448-453.

Kumpulainen, J., Raittila A.-M., Lehto, J. \& Koivistoinen, P. 1983. Electrothermal atomic absorption spectrometric determination of selenium in foods and diets. Journal of the Association of Official Analytical Chemists 66: 1129-1135.

Mahan, D.C. \& Moxon A.L. 1978. Effects of adding inorganic and organic selenium sources to the diets of young swine. Journal of Animal Science 47: 456-466.

Mayland, H.F. 1994. Selenium in plant and animal nutrition. In: Frankenberger, W.T. Jr. \& Benson, S. (eds.). Selenium in the environment. Marcel Dekker, Inc. New York. p. 29-45.
Oldfield, J.E. 1987. Two faces of selenium. Journal of Nutrition 117: 2002-2008.

Peterson, P.J. \& Burler, G.W. 1962. The uptake and assimilation of selenite by higher plants. Australian Journal of Biological Sciences 15: 126-146.

Piironen, V., Syväoja, E.-L., Varo, P., Salminen, K. \& Koivistoinen, P. 1986. Tocopherols and tocotrienols in Finnish foods: vegetables, fruits and berries. Journal of Agricultural and Food Chemistry 34: 742-746.

Sankari, S. 1985. Plasma glutathione peroxidase and tissue selenium response to selenium supplementation in swine. Acta Veterinaria Scandinavica 81: 1-127.

Shrift, A. \& Virupaksha, T.K. 1965. Seleno-amino acids in selenium-accumulating plants. Biochimica et Biophysica Acta 100: 65-75.

Sippola, J. 1979. Selenium content of soils and timothy (Phleum pratense L.) in Finland. Annales Agriculturae Fenniae 18: 182-187.

Shepherd, L. \& Huber, R.E. 1969. Some chemical and biochemical properties of selenomethionine. Canadian Journal of Biochemistry 47: 877-881.

Varo, P. 1983. Selenium fertilization in Finland: selenium content in feed and foods. Norwegian Journal of Agricultural Science Supplement 11: 151-158.

Yang, G., Wang, W., Zhou, R. \& Sun, S. 1983. Endemic selenium intoxication of humans in China. American Journal of Clinical Nutrition 37: 872-881.

Yläranta, T. 1983. Effect of added selenite and selenate on the selenium content of rye grass (Lolium multiflorum ) in different soils. Annales Agriculturae Fenniae 22: 139-151.

Xue, T., Hou, S. \& Tan, J. 1993. The antioxidative function of selenium in higher plants. I The inhibitive effect of selenium in lipid peroxidation and its enzymatic mechanism approaching. Chinese Science Bulletin 38: 274-277. (In Chinese).

Zhen, D., Li, R. \& Wang, W. 1982. The world Se deficiency belt. Acta Scientiae Circumstantiae 2: 241-249. 


\title{
AGRICULTURAL AND FOOD SCIENCE IN FINLAND
}

Vol. 6 (1997): 381-387.

\section{SELOSTUS}

\section{Seleenilannoituksen vaikutus raiheinän ja salaatin laatuun}

\author{
Helinä Hartikainen, Päivi Ekholm, Vieno Piironen, Tailin Xue, Terhi Koivu ja Markku Yli-Halla \\ Helsingin yliopisto ja Kiinan tiedeakatemia
}

Seleeni on ihmisille ja eläimille välttämätön alkuaine, jonka puute yhdessä E-vitamiinin puutteen kanssa lisää hapettumisvaurioiden riskiä soluissa. Suurina annoksina se on kuitenkin myrkyllinen. Suomessa maaperässä on luontaisesti vähän kasveille käyttökelpoista seleeniä, minkä vuoksi sitä on vuodesta 1984 lisätty moniravinteisiin lannoitteisiin, jotta elintarvikkeiden seleenipitoisuus olisi ravitsemuksen kannalta riittävä. Seleenin merkitys kasveissa on kuitenkin vielä epäselvä. Tämän vuoksi tehtiin astiakoe, jossa alustavasti selvitettiin, miten nousevina määrinä annettu lannoiteseleeni vaikutti kasvien kemialliseen koostumukseen ja antioksidatiivisiin ominaisuuksiin. Koekasveina käytettiin raiheinää ja salaattia. Seleenilisäyksen noustessa kasvoi liukoisiin ja liukenemattomiin valkuaisaineisiin sitoutuneen selee- nin suhteellinen osuus samalla kun vapaissa aminohapoissa olevan osuus pieneni. Tämä osoittaa, että kasvin ottamaa seleeniä käytettiin tehokkaasti proteiinisynteesissä. Seleenilannoitus vaikutti myös kasvien antioksidatiivisiin ominaisuuksiin. Molemmissa kasveissa havaittiin glutationi-peroksidaasientsyymin (GSH-Px) aktiivisuuden lisääntyvän seleenilisäyksen noustessa, mikä viittaa siihen, että korkeammissa kasveissa toimii samantapainen seleenistä riippuva GSH-Px kuin eläimissä. GSH-Px:n aktiivisuuden kasvaessa väheni kuitenkin toisen antioksidatiivisen entsyymin, superoksididismutaasin (SOD) aktiivisuus ja E-vitamiinin pitoisuus pieneni. Tulos viittaa siihen, että samalla kun seleeni nosti GSH-Px:n aktiivisuutta se vähensi muiden antioksidanttien tarvetta. 